\title{
Inheritance of Resistance to Sorghum Shoot Fly, Atherigona soccata
}

\author{
M. K. Dhillon,* H. C. Sharma, B. V. S. Reddy, Ram Singh, and J. S. Naresh
}

\section{ABSTRACT}

The sorghum shoot fly, Atherigona soccata Rond. (Diptera: Muscidae), is one of the most important pests of sorghum [Sorghum bicolor (L.) Moench], and host plant resistance is an important component for the management of this pest. Most of the sorghum hybrids currently under cultivation are based on cytoplasmic malesterility (CMS). To develop a strategy to develop sorghum hybrids with resistance to shoot fly, we studied the nature of gene action for resistance to this pest in $F_{1}$ hybrids derived from shoot fly-resistant and -susceptible CMS and restorer lines. The hybrids based on shoot flyresistant CMS and restorer lines were glossy and trichomed and had lower proportion of plants with eggs (78.5\% vs. 88.4 to $93.3 \%)$ and deadhearts $(40.8 \%$ vs. 60.8 to $75.3 \%)$ than the hybrids based on other cross combinations, suggesting that resistance is required in both CMS and restorer lines for obtaining shoot fly-resistant hybrids. Proportional contributions of CMS lines for oviposition, deadhearts, leaf glossiness, and recovery resistance were greater than those of the restorer lines. The general (GCA) and specific combining ability (SCA) estimates suggested that inheritance for oviposition nonpreference, deadhearts, recovery resistance, and the morphological traits associated with resistance or susceptibility to $A$. soccata were governed by additive-type of gene action. The SCA effects and heterosis estimates indicated that heterosis breeding would not be rewarding in breeding for resistance to shoot fly.

$\mathrm{S}$ ORGHUM is an important crop in Asia, Africa, USA, Australia, and Latin America. It is grown on about 10.4 million hectares in India, with an annual grain production of 8 million megagrams (FAO, 2002). The productivity levels under subsistence farming conditions are quite low (500-800 $\mathrm{kg} \mathrm{ha}^{-1}$ ) mainly because of biotic and abiotic constraints. More than 150 species of insect pests damage the sorghum crop, of which sorghum shoot fly is most important in Asia, Africa, and the Mediterranean Europe (Sharma, 1993). Losses in grain yield because of shoot fly damage average about $5 \%$ in India (Jotwani, 1983). The shoot fly females lay white, elongated, cigarshaped eggs singly on the undersurface of the leaves, parallel to the midrib. After egg hatching, the larvae crawl to the plant whorl and move downward between the folds of the young leaves until they reach the growing point. When they feed, they cut the growing tip and the result is drying of the central leaf called "deadheart."

M.K. Dhillon, International Crops Research Institute for the SemiArid Tropics (ICRISAT), Patancheru 502 324, India, and Chaudhary Charan Singh Haryana Agricultural University, Hisar 125 004, India; H.C. Sharma and B.V.S. Reddy, International Crops Research Institute for the Semi-Arid Tropics (ICRISAT), Patancheru 502 324, India; R. Singh and J.S. Naresh, Chaudhary Charan Singh Haryana Agricultural University, Hisar 125 004, India. Received 13 June 2005. *Corresponding author (m.dhillon@cgiar.org; mukeshdhillon@ rediffmail.com).

Published in Crop Sci. 46:1377-1383 (2006).

Crop Breeding \& Genetics

doi:10.2135/cropsci2005.06-0123

(C) Crop Science Society of America

677 S. Segoe Rd., Madison, WI 53711 USA
A number of genotypes with resistance to shoot fly have been identified, but the levels of resistance are low to moderate (Sharma et al., 2003a). Plant resistance to sorghum shoot fly appears to be a complex trait and depends on the interplay of a number of component characters (Dhillon, 2004).

The discovery of CMS (Stephens and Holland, 1954) made it easier to incorporate desired traits into hybrids (House, 1985). Because more than $75 \%$ of the area under sorghum cultivation in India is planted to highyielding hybrids, and most of these hybrids are based on milo-cytoplasm, it is important to transfer genes conferring resistance to sorghum shoot fly into cytoplasmic male-sterile (A-lines), maintainer (B-lines), and restorer (R-lines) lines to develop hybrids with high grain yield and resistance to this pest.

There is no information on the interaction between shoot fly-resistant and -susceptible A-, B-, and R-lines relative to the expression and inheritance of resistance to A. soccata in $\mathrm{F}_{1}$ hybrids. Since future breeding efforts will largely focus on high-yielding, shoot fly-resistant hybrids, the present studies were performed to understand the nature of gene action for components that contribute to resistance or susceptibility to $A$. soccata. Such an information will be useful in developing an appropriate strategy to produce shoot fly-resistant hybrids for cultivation by the farmers in the semiarid tropics.

\section{MATERIALS AND METHODS \\ Experimental Material}

The experimental material consisted of 12 restorer, $12 \mathrm{CMS}$, and their maintainer ( 5 shoot fly-susceptible and 7 shoot flyresistant) lines selected at random from germplasm and breeding material maintained in the gene bank at the International Crops Research Institute for the Semi-Arid Tropics, Patancheru, Andhra Pradesh, India. The prehybridization evaluation of CMS, maintainer, and restorer lines for reaction to sorghum shoot fly (determined on the basis of percentage deadhearts) during the 2002 rainy season supplemented with an ex-ante inference was used to categorize the test material into shoot fly-resistant and -susceptible groups. The $144 \mathrm{~F}_{1}$ hybrids were produced by crossing $12 \mathrm{CMS}$ with 12 restorer lines in a line $\times$ tester mating design during the 2002-2003 post-rainy season.

The test material (12 A-, B-, and R-lines, and their $144 \mathrm{~F}_{1}$ hybrids), along with shoot fly-resistant (IS 18551) and susceptible (Swarna) checks, was planted in a randomized complete block design (RCBD) in three replications during the 2003 rainy (July-November), early post-rainy (SeptemberJanuary), and late post-rainy (October-March) seasons using the interlard fish-meal technique (Soto, 1974). Each genotype was sown in four-row plots of 2-m row length; the rows were $75 \mathrm{~cm}$ apart. The seed was sown with a four-cone planter at a depth of $5 \mathrm{~cm}$. The plants were thinned $1 \mathrm{wk}$ after seedling emergence to maintain a spacing of $10 \mathrm{~cm}$ between plants.

Data were recorded in the central two rows on oviposition and deadheart formation at $14 \mathrm{~d}$ after seedling emergence 
(DAE). Recovery resistance was assessed on a scale of 1 to 9 $(1=>80 \%$ plants with 2 to 3 uniform productive tillers; and $9=$ $<20 \%$ damaged plants with 1 to 2 productive tillers) at maturity. Data were also recorded on leaf glossiness on a scale of 1 to 5 [1 = highly glossy (light green, shining, narrow, and erect leaves), and $5=$ nonglossy (dark green, dull, broad, and drooping leaves)] (Sharma and Nwanze, 1997). At 12 DAE, trichome density was recorded on central portion of the fifth leaf (from the base) from three seedlings in each genotype at random. The leaf pieces were cleared in acetic-lactic acid (2:1) (Maiti et al., 1980; Dhillon, 2004) and observed for the presence of trichomes and trichome density on the abaxial (lower) and adaxial (upper) surfaces of the leaves. The leaf sections were mounted on a slide in a drop of lactic acid and observed under a microscope at a magnification of $10 \times$. Pigmentation of the plumule and leaf sheath was assessed on a 1 -to- 5 rating scale $(1=$ plumule or leaf sheath with a deep pink pigment, 2 = plumule or leaf sheath with a pink pigment, $3=$ plumule or leaf sheath with light pink pigment, $4=$ plumule or leaf sheath with very light pink pigment, $5=$ plumule or leaf sheath of green color) at 5 DAE. Chlorophyll content $\left(\mathrm{g} \mathrm{m}^{-2}\right)$ was measured with a chlorophyll meter (SPAD-502, Minolta Corporation) on the flag leaf (three leaves per plot) at $80 \mathrm{~d}$ after seedling emergence (Yamamoto et al., 2002). Waxy bloom was recorded on a scale of 1 to $5(1=$ stem and leaves without a wax layer, and $5=$ stem and leaves covered with a dense layer of wax) at $50 \%$ flowering.

\section{Statistical Analyses}

The data were subjected to analyses of variance. The parents were classified as resistant and susceptible on the basis of their reaction to shoot fly. Genetic analyses were performed via a line $\times$ tester method, as suggested by Kempthrone (1957), using GenStat Release 6.0. The sum of squares due to $F_{1}$ hybrids was partitioned into sum of squares due to females, males, and females $\times$ males, which was used to estimate the additive and dominance components of the variation. Simple correlations, multiple regression, and stepwise regression analyses were performed to understand the association between the morphological traits and resistance to sorghum shoot fly (Sharma et al., 2003b).
The main effects of CMS and restorer lines were equivalent to general combining ability (GCA), and the effects of a CMS line with a specific restorer were equivalent to specific combining ability (SCA) (Hallauer and Miranda, 1981). The heritability [Narrow-sense heritability $=\{(V$ gca $) /(V$ gca $+V$ sca + $\mathrm{VE})\} \times 100$; where, $V$ gca $=$ general combining ability variance, $V$ sca $=$ specific combining ability variance, and $\mathrm{VE}=$ error variance], and the proportional contribution of females, males, and their interaction [contribution of females $=\{\mathrm{SS}$ (females) $\mathrm{SS}($ crosses $)\} \times 100$; contribution of males $=\{\mathrm{SS}$ (males) $/ \mathrm{SS}$ (crosses) $\} \times 100$; contribution of females $\times$ males interaction $=$ [SS (females $\times$ males $) / S S$ (crosses) $\times 100\}]$ to total variability of each trait/character was also computed.

\section{RESULTS AND DISCUSSION}

\section{Oviposition Preference and Deadheart Formation}

Deadheart formation due to shoot fly damage was greatest during the rainy season, followed by early postrainy, and the late post-rainy seasons, but there was no change in the relative resistance-susceptibility rankings of the material tested across seasons. The shoot flyresistant CMS lines were preferred for oviposition (76.3\% plants with eggs) and suffered more deadheart incidence $(40.1 \%$ deadhearts) than the maintainer lines (68.4\% plants with eggs and $32.5 \%$ plants with deadhearts), while the differences among the shoot flysusceptible CMS and maintainer lines were not apparent (Table 1). Preference of CMS lines for oviposition and more deadhearts formation as compared with the maintainers suggested that the resistance-susceptibility to $A$. soccata was influenced by factors associated with male-sterility or fertility restoration cytoplasm in sorghum. Similar findings have earlier been reported in case of sorghum midge, Stenodiplosis sorghicola (Coq.) (Sharma et al., 1994). The hybrids based on shoot flyresistant CMS and restorer lines had significantly lower proportion of plants with eggs and deadhearts than the

Table 1. Reaction of cytoplasmic male-sterile (A), maintainer (B), and restorer (R) lines of sorghum and their F1 hybrids to Atherigona soccata, and the morphological traits associated with resistance to this insect across seasons (ICRISAT, Patancheru, India).

\begin{tabular}{|c|c|c|c|c|c|c|c|c|c|c|}
\hline \multirow{2}{*}{$\begin{array}{l}\text { Hybrid and } \\
\text { parent groups }\end{array}$} & \multirow{2}{*}{$\begin{array}{l}\text { Plants with } \\
\text { eggs }(\%)\end{array}$} & \multirow[b]{2}{*}{ Deadhearts (\%) } & \multirow{2}{*}{$\begin{array}{c}\text { Recovery } \\
\text { resistance score } \dagger\end{array}$} & \multirow{2}{*}{$\begin{array}{c}\text { Leaf } \\
\text { glossiness score } \neq\end{array}$} & \multicolumn{2}{|c|}{$\begin{array}{c}\text { Trichome } \\
\text { density }\end{array}$} & \multicolumn{2}{|c|}{ Pigmentation score $\$$} & \multirow{2}{*}{$\begin{array}{c}\text { Chlorophyll } \\
\text { content }\end{array}$} & \multirow{2}{*}{$\begin{array}{c}\text { Waxy } \\
\text { bloom score }\end{array}$} \\
\hline & & & & & abaxial & adaxial & Plumule & Leaf sheath & & \\
\hline RA\#\# & 76.3 & 40.1 & 6.0 & 2.4 & 62.8 & 96.0 & 2.7 & 3.3 & 43.3 & 4.9 \\
\hline $\mathbf{R B}+\dagger$ & 68.4 & 32.5 & 5.6 & 2.0 & 79.2 & 120.2 & 2.7 & 3.4 & 41.2 & 4.9 \\
\hline $\mathbf{S A}+4$ & 88.4 & 64.5 & 7.1 & 4.8 & 0.2 & 0.4 & 3.6 & 4.1 & 47.7 & 5.0 \\
\hline SB§§ & 90.6 & 67.4 & 7.3 & 4.8 & 4.6 & 10.6 & 4.1 & 4.3 & 47.2 & 4.9 \\
\hline RR II & 74.3 & 39.3 & 4.4 & 1.7 & 94.8 & 137.6 & 2.0 & 2.5 & 45.2 & 4.4 \\
\hline SR\#\# & 90.6 & 69.6 & 6.4 & 4.0 & 1.6 & 3.7 & 3.1 & 4.1 & 46.3 & 5.0 \\
\hline $\mathbf{R A} \times \mathbf{R} \mathbf{R} \dagger \dagger$ & 78.5 & 40.8 & 4.7 & 2.2 & 94.5 & 141.1 & 2.2 & 2.9 & 46.4 & 4.7 \\
\hline $\mathbf{R A} \times \mathbf{S R}+\boldsymbol{+}+$ & 88.4 & 60.8 & 5.7 & 3.9 & 19.8 & 31.7 & 2.7 & 3.8 & 47.5 & 4.9 \\
\hline $\mathbf{S A} \times \mathbf{R} \mathbf{R}+\boldsymbol{\dagger}$ & 93.0 & 69.1 & 4.8 & 4.5 & 32.3 & 49.9 & 2.1 & 3.0 & 48.8 & 5.0 \\
\hline $\mathbf{S A} \times \mathbf{S R}+\boldsymbol{\dagger} \dagger$ & 93.3 & 75.3 & 5.8 & 4.7 & 1.2 & 1.9 & 3.1 & 4.0 & 49.0 & 5.0 \\
\hline $\operatorname{LSD}(P=0.05)$ & 12.99 & 5.50 & 0.76 & 0.54 & 12.35 & 16.37 & 0.67 & 0.61 & NS & NS \\
\hline
\end{tabular}

$\dagger$ Recovery resistance score $(1=>80 \%$ plants with 2 to 3 uniform productive tillers, and $9=<20 \%$ damaged plants with 1 to 2 productive tillers).

+ Leaf glossiness score $(1=$ highly glossy, and $5=$ nonglossy $)$.

$\S$ Pigmentation score $(1=$ dark green pink color, and $5=$ light yellow color $)$.

II Waxy bloom score $(1$ = stem without wax layer, and 5 = stem densely covered with wax layer).

\# RA = Shoot fly-resistant A-lines.

$\dagger \mathbf{R B}=$ Shoot fly-resistant B-lines.

$\uparrow+$ SA $=$ Shoot fly-susceptible A-lines.

$\S \S S B=$ Shoot fly-susceptible B-lines.

II $R R=$ Shoot fly-resistant R-lines.

\#\# SR = Shoot fly-susceptible R-lines.

$\uparrow \uparrow \uparrow$ Hybrid combinations. 
hybrids on the basis of other cross combinations. Hybrids based on shoot fly-resistant CMS and-susceptible restorer lines had comparatively lower percentage of plants with eggs and deadhearts than the hybrids based on shoot fly-susceptible CMS and resistant or susceptible restorer lines. The hybrids based on shoot fly-susceptible CMS and shoot fly-resistant restorer lines were as susceptible as the hybrids based on shoot flysusceptible CMS and restorer lines, suggesting the influence of cytoplasmic factors on expression of shoot fly resistance in sorghum because of the interaction between cytoplasmic and nuclear genes (Dhillon, 2004). Similar results on the influence of CMS on genotypic susceptibility have also been reported by $\mathrm{Xu}$ and Song (1997) and Xu et al. (1998) for bacterial leaf blight, caused by Xanthomonas oryzae pv. oryzae (Ishiyama) Swings et al. $=X$. campestris pv. oryzae (Ishiyama) Dye in rice (Oryza sativa L.) and by Sharma et al. (1996) for sorghum midge in sorghum.

\section{Recovery Resistance}

Shoot fly-resistant CMS and maintainer lines showed better recovery resistance (score 5.6-6.0) as compared with the susceptible CMS and maintainer lines (score 7.1-7.3) (Table 1). Hybrids based on shoot fly-susceptible CMS and restorer lines showed poor recovery resistance than the hybrids based on other cross combinations. Varieties with high recovery resistance are known to yield more under shoot fly infestation (Rana et al., 1985).

\section{Morphological Traits}

Shoot fly-resistant CMS, maintainer, and restorer lines were glossy (score 1.7-2.4), while the shoot flysusceptible CMS, maintainer, and restorer lines were nonglossy (score 4.0-4.8) (Table 1). The hybrids based on the glossy CMS and restorer lines showed the same level of glossiness as the parents, whereas the hybrids based on the nonglossy CMS lines and glossy or nonglossy restorer lines were nonglossy. However, the hybrids based on glossy CMS lines and nonglossy restorer lines were intermediate in expression of leaf glossiness. Expression of leaf glossiness in $F_{1}$ hybrids was influenced more by the CMS than by the restorer lines, possibly because of interaction of cytoplasmic and nuclear genes (Dhillon, 2004).

The adaxial surface of the leaf had more trichomes than the abaxial leaf surface. The shoot fly-resistant CMS, maintainer, and restorer lines were trichomed, whereas the shoot fly-susceptible CMS, maintainer, and restorer lines were nontrichomed, except the restorer Swarna (Table 1). The hybrids based on the trichomed CMS and restorer lines had more trichomes compared with the parents. Hybrids based on nontrichomed CMS and trichomed restorer lines had fewer trichomes than the trichomed parent, except the hybrids based on restorer parent SFCR 125. The hybrids based on nontrichomed CMS and restorer lines were nontrichomed, while the hybrids based on trichomed CMS and nontrichomed restorer lines were nontrichomed, except for the hybrids based on ICSV 91011 and Swarna as restorer parents. The restorer lines showed a greater influence on expression of trichomes in the $F_{1}$ hybrids. The level of resistance to shoot fly was higher when both glossy and trichome traits occurred together (Agrawal and House, 1982; Dhillon et al., 2005).

The intensity of leaf sheath and plumule pigmentation was greater for shoot fly-resistant CMS, maintainer, and restorer lines as compared with the susceptible ones (Table 1). The hybrids based on tan-type (nonpigmented) CMS and restorer parents were also tan type. The restorer lines influenced expression of pigmentation in plumule and leaf sheath. Purple-pigmented sorghums have been reported to be tolerant to shoot fly damage (Singh et al., 1981), but genetically diverse sorghum material used in the present studies did not support this hypothesis. The chlorophyll content of the flag leaf at 80 DAE in shoot fly-resistant CMS and maintainer lines was lower than that of the shoot fly-susceptible CMS and maintainer lines (Table 1). There were no differences in the chlorophyll content of shoot fly-susceptible CMS, maintainer, and restorer lines, and the $F_{1}$ hybrids. Shoot fly-resistant lines showed lower chlorophyll content than the susceptible ones. Mate et al. (1996) also reported higher chlorophyll content in the shoot flysusceptible than the shoot fly-resistant sorghum genotypes. The differences were nonsignificant for waxy bloom among the hybrids and their parents.

\section{Association between Shoot Fly Damage Parameters and Morphological Traits}

Resistance to shoot fly (deadhearts, plants with eggs, and recovery resistance) was associated with leaf glossiness $\left(r=0.45^{* *}\right.$ to $\left.0.88^{* *}\right)(* * P=0.01)$, trichome density $(r=-0.50 * *$ to $-0.74 * *)$, leaf sheath pigmentation $(r=0.19 * *$ to $0.54 * *)$, and waxy bloom $(r=0.27 * *$ to $\left.0.41^{* *}\right)$. Chlorophyll content was significantly and positively associated with oviposition $(r=0.42 * *)$ and deadhearts $\left(r=0.45^{* *}\right)$. Pigmentation on plumule was positively associated with recovery resistance $(r=$ $\left.0.43^{* *}\right)$. Leaf glossiness, trichome density on both the leaf surfaces, leaf sheath pigmentation, and waxy bloom were significantly and positively correlated $(r=0.24 * *$ to $0.96^{* *}$ ) with one another. Chlorophyll content showed significant and negative association with leaf glossiness, trichome density, and waxy bloom. Morphological traits and plants with eggs explained $86.0 \%$ of the total variation in shoot fly deadhearts [Deadhearts $(\%)=$ $74.4+0.27 X_{1}+3.26 X_{2}^{*}+0.74 X_{3}-0.76 X_{4}+1.23 X_{5}^{*}-$ $\left.0.05 X_{6}+0.02 X_{7}+0.54 X_{8}\left(R^{2}=86.0 \%\right)(* P=0.05)\right]$ [where, $X_{1}=$ chlorophyll content; $X_{2}=$ leaf glossiness; $X_{3}=$ leaf sheath pigmentation; $X_{4}=$ plumule pigmentation; $X_{5}=$ plants with eggs; $X_{6}=$ trichome density (adaxial); $X_{7}=$ trichome density (abaxial); and $X_{8}=$ waxy bloom.]. Adjusted R-squared stepwise regression analyses indicated that leaf glossiness $\left(X_{2}\right)$, trichome density on adaxial surface of leaves $\left(X_{6}\right)$, and plants with eggs $\left(X_{5}\right)$ explained $86.0 \%$ of the variation in deadhearts $\left[\right.$ Deadhearts $(\%)=-65.12+3.28 X_{2}+1.31 X_{5}-0.03 X_{6}$ $\left.\left(R^{2}=86.0 \%\right)\right]$. 


\section{General Combining Ability (GCA) Effects}

\section{Oviposition Preference and Deadheart Formation}

The mean squares for hybrids, CMS lines, restorers, CMS lines $\times$ restorers, and for their interactions with the environments were statistically significant at $P=0.05$ or 0.01 for percentage plants with eggs and deadhearts, except environments $\times$ CMS lines $\times$ restorers for deadhearts (Table 2). The GCA effects for oviposition preference and deadheart incidence for the shoot flyresistant CMS and restorer lines were significant and negative, except in few cases; whereas such effects for shoot fly-susceptible parents were positive (Table 3). Similar observations have been reported by Sharma et al. (1977) and Hallali et al. (1982). The parental performance was a good indicator of hybrid behavior as has been reported by Rao et al. (1974). The proportional contribution of CMS lines for percentage plants with eggs and deadhearts was greater than that of the restorer lines (Table 3). The narrow-sense heritabilities for oviposition and deadhearts were 15.0 and $12.8 \%$, respectively, and estimates of additive variances for these traits were greater than their dominance variances (Table 4), suggesting the role of additive-type of gene action conditioning these traits. As oviposition nonpreference and deadheart formation being governed by additive-type of gene action, resistance in both male and female parents would be required for obtaining hybrids with resistance to shoot fly. Similar inheritance pattern of these traits was reported by Rao et al. (1974), Hallali et al. (1983), and Agrawal and Abraham (1985). Ravindrababu and Pathak (2000) suggested additive and epistatic gene effects for resistant $\times$ resistant crosses whereas for resistant $\times$ susceptible crosses additive, dominance, and epistatic (additive $\times$ dominance) effects were important for resistance to shoot fly.

\section{Recovery Resistance}

The mean squares for recovery resistance for environments $\times$ hybrids, environments $\times$ CMS lines, and environments $\times$ restorers were significant at $P=0.05$ or

Table 2. Mean squares for shoot fly (Atherigona soccata) oviposition preference, deadhearts, and recovery resistance in $F_{1}$ sorghum hybrids and their parents (ICRISAT, Patancheru, India).

\begin{tabular}{|c|c|c|c|c|}
\hline $\begin{array}{l}\text { Source of } \\
\text { variation }\end{array}$ & df & $\begin{array}{l}\text { Plants with } \\
\text { eggs (\%) }\end{array}$ & Deadhearts (\%) & $\begin{array}{l}\text { Recovery } \\
\text { resistance }\end{array}$ \\
\hline Environments (E) & 2 & $54008.6 * *$ & $130408.3 * *$ & 417.3** \\
\hline Hybrids & 143 & $555.6^{* * *}$ & $2246.7 * *$ & $7.7 * *$ \\
\hline Males (M) & 11 & 3732.2** & $17069.6 * *$ & $11.8 * *$ \\
\hline Females (F) & 11 & 1241.0** & $6751.8 * *$ & $\mathbf{5 9 . 1} * *$ \\
\hline Males $\times$ females & 121 & $200.2 * *$ & 489.7* & $2.7 * *$ \\
\hline Environments $\times$ hybrids & 284 & $209.4 * *$ & 219.9*** & $2.6 * *$ \\
\hline Environments $\times$ females & 22 & $999.3 * *$ & $324.6 * *$ & $7.2 * *$ \\
\hline Environments $\times$ males & 22 & 444.9** & $369.8 * *$ & $7.4 * *$ \\
\hline $\mathbf{E} \times \mathbf{F} \times \mathbf{M}$ & 240 & $115.8 * *$ & 196.6 & 1.7 \\
\hline Error & 854 & 69.1 & 158.0 & 1.6 \\
\hline \multicolumn{5}{|c|}{ Proportional contribution $(\%)$ to total variance } \\
\hline Females & & 52.01 & $\mathbf{5 8 . 4 4}$ & 11.76 \\
\hline Males & & 17.30 & 23.12 & 59.06 \\
\hline Females $\times$ males & & 30.69 & 18.44 & 29.18 \\
\hline
\end{tabular}

* $\boldsymbol{F}$ test significant at 0.05 probability level.

** $\boldsymbol{F}$ test significant at 0.001 probability level.
Table 3. General combining ability (GCA) effects of 12 cytoplasmic male-sterile (CMS) and restorer lines of sorghum for shoot fly (Atherigona soccata) oviposition preference (plants with eggs), deadhearts, and recovery resistance (ICRISAT, Patancheru, India).

\begin{tabular}{|c|c|c|c|}
\hline Genotypes & $\begin{array}{l}\text { Plants with } \\
\text { eggs }(\%)\end{array}$ & Deadhearts (\%) & $\begin{array}{l}\text { Recovery } \\
\text { resistance }\end{array}$ \\
\hline \multicolumn{4}{|c|}{ Shoot fly-resistant CMS lines } \\
\hline SPSFR 94011A & $-4.68 * *$ & $-8.41 * *$ & $-0.26^{*}$ \\
\hline SPSFR 94006A & $-4.32 * *$ & $-8.98 * *$ & $-\mathbf{0 . 1 9}$ \\
\hline SPSFR 94007A & $-2.20 * *$ & $-5.74 * *$ & $-\mathbf{0 . 1 3}$ \\
\hline SPSFR 94010A & -0.96 & $-2.73^{*}$ & $0.64 * *$ \\
\hline SPSFR 94034A & $-\mathbf{4 . 8 6} * *$ & $-10.07 * *$ & 0.12 \\
\hline SP 55299A & $-\mathbf{3 . 3 1} * *$ & $-7.88 * *$ & $-\mathbf{0 . 2 9} * *$ \\
\hline SP 55301A & $-10.36 * *$ & $-21.69 * *$ & -0.01 \\
\hline \multicolumn{4}{|c|}{ Shoot fly-susceptible CMS lines } \\
\hline SPSFR 94012A & $4.74 * *$ & $8.35^{* *}$ & $-\mathbf{0 . 5 2} * *$ \\
\hline $296 A$ & $6.20 * *$ & $11.21 * *$ & 0.16 \\
\hline Tx 623A & $7.40 * *$ & $17.94 * *$ & $0.44 * *$ \\
\hline CK 60A & $6.47 * *$ & $15.40 * *$ & $-\mathbf{0 . 1 8}$ \\
\hline ICSA 42A & $\mathbf{5 . 8 7} * *$ & $12.60 * *$ & $\mathbf{0 . 2 2}$ \\
\hline $\mathbf{S E} \pm(\mathbf{G C A})$ & 0.80 & 1.21 & 0.12 \\
\hline $\mathrm{SE} \pm\left(g_{i}-g_{j}\right)$ & 1.13 & 1.71 & 0.17 \\
\hline \multicolumn{4}{|c|}{ Shoot fly-resistant restorer lines } \\
\hline ICSV 705 & $-\mathbf{4 . 7 0} * *$ & $-5.56 * *$ & $0.24 *$ \\
\hline ICSV 700 & -0.99 & -2.07 & $-0.80 * *$ \\
\hline ICSV 708 & -1.44 & $-\mathbf{4 . 4 8} * *$ & $-\mathbf{0 . 8 3} * *$ \\
\hline PS 30710 & -0.26 & $-6.29 * *$ & $-0.81^{* *}$ \\
\hline IS 18551 & $-4.49 * *$ & $-8.60 * *$ & $-\mathbf{0 . 4 5} * *$ \\
\hline SFCR 151 & $-\mathbf{3 . 1 6} * *$ & $-\mathbf{7 . 0 8} * *$ & $\mathbf{0 . 7 3} * *$ \\
\hline SFCR 125 & $-2.38 * *$ & $-7.71 * *$ & $-0.95 * *$ \\
\hline \multicolumn{4}{|c|}{ Shoot fly-susceptible restorer lines } \\
\hline ICSV 91011 & $1.90 *$ & $3.21 * *$ & 0.08 \\
\hline CS 3541 & $3.40 * *$ & $6.67 * *$ & $\mathbf{0 . 3 3} * *$ \\
\hline MR 750 & 4.50** & $12.16 * *$ & $\mathbf{0 . 8 0} * *$ \\
\hline ICSV 745 & $4.46 * *$ & $12.27 * *$ & $0.97 * *$ \\
\hline Swarna & $3.16 * *$ & $7.49 * *$ & $\mathbf{0 . 7 3} * *$ \\
\hline $\mathrm{SE} \pm$ (GCA) & 0.80 & 1.21 & 0.12 \\
\hline $\mathrm{SE} \pm\left(g_{i}-g_{j}\right)$ & 1.13 & 1.71 & 0.17 \\
\hline
\end{tabular}

* GCA effects significant at $P=0.05$.

$* *$ GCA effects significant at $P=0.01$.

0.01 (Table 2). The proportional contribution of restorer lines was more than that of the CMS lines for recovery resistance. The GCA effects for recovery resistance were significant and negative for the CMS lines SPSFR 94011, SPSFR 94012, and SP 55299 but significant and positive for SPSFR 94010 and Tx 623 (Table 3). The GCA effects for recovery resistance of the shoot flyresistant restorer lines were significant and negative, whereas those of the shoot fly-susceptible restorers were

Table 4. Additive and dominance variances, and narrow-sense heritability for oviposition preference, deadhearts, recovery resistance, leaf glossiness, trichome density, plant pigmentation, chlorophyll content, and waxy bloom in sorghum (ICRISAT, Patancheru, India).

\begin{tabular}{|c|c|c|c|}
\hline \multirow[b]{2}{*}{ Traits } & \multicolumn{2}{|c|}{ Genotypic variance } & \multirow{2}{*}{$\begin{array}{c}\text { Narrow-sense } \\
\text { heritability (\%) }\end{array}$} \\
\hline & $\boldsymbol{\sigma}^{2} \mathbf{A}$ & $\sigma^{2} \mathbf{D}$ & \\
\hline Plants with eggs (\%) & $42.34 * *$ & $14.56 * *$ & 15.0 \\
\hline Deadhearts (\%) & $211.50 * *$ & $36.86^{*}$ & 12.8 \\
\hline Recovery resistance & $1.36 * *$ & 0.12 & 22.0 \\
\hline Leaf glossiness & $0.94 * *$ & $0.20 *$ & 60.5 \\
\hline Trichome density (adaxial) & 3343.78** & 784.42** & 1.0 \\
\hline Trichome density (abaxial) & 1583.1 & $500.13 * *$ & 1.1 \\
\hline Plumule pigmentation & $0.54 * *$ & $0.13 * *$ & 45.7 \\
\hline Leaf sheath pigmentation & $\mathbf{0 . 5 0} * *$ & $0.06 * *$ & 39.9 \\
\hline Waxy bloom & $0.05 * *$ & $\mathbf{0 . 0 3} * *$ & 35.1 \\
\hline Chlorophyll content & $5.35 * *$ & $2.84 * *$ & 23.9 \\
\hline
\end{tabular}

* Significant at $P=\mathbf{0 . 0 5}$.

$* *$ Significant at $\boldsymbol{P}=\mathbf{0 . 0 1}$. 
significant and positive, except in a few cases. Additivetype of gene action was involved in recovery resistance (Table 4). However, earlier studies suggested predominance of additive, nonadditive, and epistatic (resistant $X$ susceptible) type of gene action for recovery resistance (Starks et al., 1970; Sharma et al., 1977; Borikar and Chopde, 1982).

\section{GCA Effects for Morphological Traits Associated with Resistance to Atherigona soccata}

The mean squares for hybrids, CMS lines, restorers, CMS lines $\times$ restorers, and for their interactions with the environments were statistically significant at $P=0.05$ or 0.01 for leaf glossiness and trichome density on abaxial and adaxial leaf surfaces, except the mean squares for environments $\times$ CMS lines for trichomes on the abaxial leaf surface (Table 5). The proportional contribution of CMS lines for leaf glossiness was more than that of the restorer lines, whereas the reverse was true for trichome density. The GCA effects for leaf glossiness of shoot flyresistant CMS and restorer lines were significant and negative, whereas those for the shoot fly-susceptible CMS and restorer lines were significant and positive (although there were a few exceptions), but the reverse was true for trichome density (Table 6). Leaf glossiness has been reported to be controlled by a single recessive gene (Tarumoto, 1980) and is simply inherited (Agrawal and House, 1982). Trichomes and leaf glossiness are independently inherited and apparently have an additive effect in reducing shoot fly incidence (Hallali et al., 1982; Maiti et al., 1984). The narrow sense heritability for leaf glossiness was 60.5 and $1.0 \%$ for trichome density.

The mean squares for CMS lines, restorers, and CMS lines $\times$ restorers were significant at $P=0.05$ or 0.01 for plumule and leaf sheath pigmentation, waxy bloom, and chlorophyll content (Table 5). The proportional contribution of restorer lines for pigmentation of plumule and leaf sheath, and waxy bloom was more than that of CMS lines, whereas the reverse was the case for chlorophyll content. The GCA effects for pigmentation of the plumule and leaf sheath of the shoot fly-resistant CMS and restorer lines were significant and negative, whereas those of shoot fly-susceptible CMS and restorers were significant and positive, except in a few cases (Table 6). The GCA effects for chlorophyll content in the CMS lines SPSFR 94010, SP 55299, and SP 55301, and the restorer lines IS 18551, SFCR 151, and ICSV 745 were significant and negative, whereas those for the CMS lines Tx 623 and CK 60, and the restorer lines PS 30710, SFCR 125, CS 3541, and Swarna were significant and positive (Table 6). The GCA effects for waxy bloom in the CMS lines SPSFR 94007, SP 55299, and SP 55301, and the restorer lines ICSV 700 and IS 18551 were significant and negative, whereas those for Tx 623A, CK 60A, ICSA 42A, and Swarna were significant and positive (Table 6). The narrow-sense heritability for plumule and leaf sheath pigmentation, chlorophyll content, and waxy bloom varied between 23.9 to $45.7 \%$, and estimates of additive variances for these traits were greater than their dominance variances (Table 4), suggesting the role of additive-type of gene action conditioning these traits.

\section{Specific Combining Ability (SCA) Effects}

The SCA effects for oviposition and deadhearts were nonsignificant, and there was positive midparent heterosis for oviposition preference and deadheart incidence, except in a few cases, suggesting that heterosis breeding would not be rewarding in breeding for resistance to shoot fly.

The SCA effects for recovery resistance were nonsignificant and showed positive heterosis, suggesting the involvement of additive-type of gene action for recovery resistance. The SCA effects for glossiness and trichome density were also nonsignificant.

\section{CONCLUSIONS}

Preference of CMS lines for damage by shoot fly as compared with the maintainers suggested the influence of factors associated with male-sterility or fertility

Table 5. Mean squares for leaf glossiness, trichome density, plant pigmentation, chlorophyll content, and waxy bloom in $F_{1}$ sorghum hybrids and their parents (ICRISAT, Patancheru, India).

\begin{tabular}{|c|c|c|c|c|c|c|c|c|}
\hline \multirow[b]{2}{*}{ Source of variation } & \multirow[b]{2}{*}{ df } & \multirow[b]{2}{*}{ Leaf glossiness } & \multicolumn{2}{|c|}{ Trichome density } & \multicolumn{2}{|c|}{ Pigmentation } & \multirow{2}{*}{$\begin{array}{c}\text { Chlorophyll } \\
\text { content }\end{array}$} & \multirow[b]{2}{*}{ Waxy bloom } \\
\hline & & & Abaxial & Adaxial & Plumule & Leaf sheath & & \\
\hline Environments (E) & 2 & 10.7 & $32299.4 * *$ & 6177.7 & - & - & - & - \\
\hline Hybrids & 143 & $10.0 * *$ & $19147.7 * *$ & $36064.4 * *$ & $\mathbf{5 . 0} * *$ & 0.1 & $335.4 * *$ & 0.3 \\
\hline Males & 11 & $66.2 * *$ & $66411.6 * *$ & $137577.6 * *$ & $11.4 * *$ & $11.5 * *$ & $103.0 * *$ & $1.3^{* *}$ \\
\hline Females & 11 & 40.0** & $116518.6^{* *}$ & 239879.9 ***⿰冫⿰亅⿱丿丶丶 & $10.0 * *$ & $7.8 * *$ & $135.3 * *$ & $0.7 * *$ \\
\hline Males $\times$ females & 121 & $2.2 * *$ & $\mathbf{5 9 7 7 . 5} * *$ & 8164.4** & $0.9 * *$ & $0.5 * *$ & 22.9** & $0.2 * *$ \\
\hline Environments $\times$ hybrids & 284 & $0.6^{* *}$ & $2397.1 * *$ & $2569.6 * *$ & $\dagger$ & $\dagger$ & $\dagger$ & $\dagger$ \\
\hline Environments $\times$ females & 22 & $2.3 * *$ & 2141.7 & $2681.6 * *$ & $\dagger$ & $\dagger$ & $\dagger$ & $\dagger$ \\
\hline Environments $\times$ males & 22 & $1.0 * *$ & $4705.5 * *$ & 2513.1 $* *$ & $\dagger$ & $\dagger$ & $\dagger$ & $\dagger$ \\
\hline $\mathbf{E} \times \mathbf{F} \times \mathbf{M}$ & 240 & $0.4 *$ & $2211.2 * *$ & $2569.5 * *$ & $\dagger$ & $\dagger$ & $\dagger$ & $\dagger$ \\
\hline Error & $854(334) \div$ & 0.4 & 1476.3 & 1104.7 & 0.5 & 0.3 & 14.3 & 0.1 \\
\hline \multicolumn{9}{|c|}{ Proportional contribution $(\%)$ to total variance } \\
\hline Females & & 50.91 & 26.71 & 29.44 & 32.30 & 31.14 & 27.64 & 17.82 \\
\hline Males & & 30.73 & 46.85 & 51.34 & 37.00 & 46.25 & 21.04 & 32.49 \\
\hline Females $\times$ males & & 18.36 & 26.44 & 19.22 & 30.70 & 22.61 & $\mathbf{5 1 . 3 2}$ & 49.69 \\
\hline
\end{tabular}

* $\boldsymbol{F}$ test significant at 0.05 probability level.

$* * \boldsymbol{F}$ test significant at 0.001 probability level.

$\uparrow$ ANOVA for single season.

$\$$ Value in the parenthesis is error degrees of freedom for pigmentation, waxy bloom, and chlorophyll content. 
Table 6. General combining ability (GCA) effects of 12 cytoplasmic male-sterile (CMS) and restorer lines of sorghum for leaf glossiness, trichome density, plant pigmentation, chlorophyll content, and waxy bloom (ICRISAT, Patancheru, India).

\begin{tabular}{|c|c|c|c|c|c|c|c|}
\hline \multirow[b]{2}{*}{ Genotypes } & \multirow[b]{2}{*}{ Leaf glossiness } & \multicolumn{2}{|c|}{ Trichome density } & \multicolumn{2}{|c|}{ Pigmentation } & \multirow[b]{2}{*}{ Chlorophyll content } & \multirow[b]{2}{*}{ Waxy bloom } \\
\hline & & Abaxial & Adaxial & Plumule & Leaf sheath & & \\
\hline \multicolumn{8}{|c|}{ Shoot fly-resistant CMS lines } \\
\hline SPSFR 94011A & $-0.49 * *$ & $36.49 * *$ & $46.75^{* *}$ & $-0.44 * *$ & $-0.41 * *$ & 0.11 & 0.01 \\
\hline SPSFR 94006A & $-\mathbf{0 . 7 3} * *$ & 21.52** & 38.37** & $-\mathbf{0 . 4 5} * *$ & $-\mathbf{0 . 4 8} * *$ & -0.66 & $-\mathbf{0 . 0 7}$ \\
\hline SPSFR 94007A & $-\mathbf{0 . 5 8} * *$ & $18.14 * *$ & 21.12** & $-\mathbf{0 . 3 7} * *$ & $-\mathbf{0 . 4 2} * *$ & 0.62 & $-\mathbf{0 . 1 8} * *$ \\
\hline SPSFR 94010A & $-\mathbf{0 . 4 3} * *$ & 1.68 & $6.46 *$ & $0.52 * *$ & $\mathbf{0 . 3 0} * *$ & $-1.53 *$ & 0.04 \\
\hline SPSFR 94034A & $-\mathbf{0 . 5 7} * *$ & $23.48 * *$ & 35.33** & $-\mathbf{0 . 1 8}$ & $\mathbf{0 . 1 7}$ & -0.47 & 0.09 \\
\hline SP 55299A & $-\mathbf{0 . 6 2} * *$ & $12.61 * *$ & 24.72** & $-0.62 * *$ & $-\mathbf{0 . 5 9} * *$ & $-1.32 *$ & $-\mathbf{0 . 2 4} * *$ \\
\hline SP 55301A & $-0.95 * *$ & $17.28 * *$ & $18.34 * *$ & $1.17 * *$ & $\mathbf{0 . 8 8}^{* *} *$ & $-2.68 * *$ & $-0.21 * *$ \\
\hline \multicolumn{8}{|c|}{ Shoot fly-susceptible CMS lines } \\
\hline SPSFR 94012A & $0.77 * *$ & $-29.11 * *$ & $-42.42 * *$ & $-0.42 * *$ & $-\mathbf{0 . 2 0} *$ & -1.15 & 0.09 \\
\hline $296 A$ & $0.94 * *$ & $-23.37 * *$ & $-\mathbf{3 4 . 2 9} * *$ & 0.38** & 0.02 & 1.07 & 0.09 \\
\hline Tx 623A & $\mathbf{0 . 8 9} * *$ & $-24.17 * *$ & $-\mathbf{3 6 . 0 3}^{* *}$ & 0.08 & $0.21 *$ & $1.24 * *$ & $0.12 *$ \\
\hline CK 60A & $0.82 * *$ & $-18.26 * *$ & $-26.4 * *$ & $-\mathbf{0 . 0 1}$ & -0.15 & $\mathbf{5 . 0 0} * *$ & $0.12 *$ \\
\hline ICSA 42A & $\mathbf{0 . 9 4} * *$ & $-36.29 * *$ & $-\mathbf{5 1 . 9 7} * *$ & $0.34 * *$ & $\mathbf{0 . 6 7} * *$ & -0.24 & 0.12* \\
\hline $\mathrm{SE} \pm($ GCA $)$ & 0.06 & 3.70 & 3.20 & 0.11 & 0.10 & 0.63 & 0.05 \\
\hline $\mathrm{SE} \pm\left(g_{i}-g_{j}\right)$ & 0.08 & 5.23 & 4.52 & 0.16 & 0.14 & 0.89 & 0.07 \\
\hline \multicolumn{8}{|c|}{ Shoot fly-resistant restorer lines } \\
\hline ICSV 705 & $-0.46 * *$ & 11.01** & $15.38 * *$ & -0.06 & -0.06 & -1.12 & -0.02 \\
\hline ICSV 700 & $-\mathbf{0 . 3 4} * *$ & $45.79 * *$ & $56.07 * *$ & $-\mathbf{0 . 8 3} * *$ & $-\mathbf{0 . 6 0} * *$ & -0.68 & $-\mathbf{0 . 3 2} * *$ \\
\hline ICSV 708 & $-0.47 * *$ & $44.88 * *$ & 72.3** & -0.15 & $-0.65 * *$ & 0.83 & 0.09 \\
\hline PS 30710 & $-\mathbf{0 . 4 9} * *$ & $27.11 * *$ & $\mathbf{3 4 . 8 6}^{* *}$ & -0.09 & $-\mathbf{0 . 5 1} * *$ & $\mathbf{2 . 4 3} * *$ & 0.09 \\
\hline IS 18551 & $-\mathbf{0 . 7 7} * *$ & $33.23 * *$ & 45.32** & $-\mathbf{0 . 3 1} * *$ & $-\mathbf{0 . 4 0} * *$ & $-3.29 * *$ & $-\mathbf{0 . 4 6} * *$ \\
\hline SFCR 151 & $\mathbf{0 . 0 5}$ & 5.58 & $17.91^{* *} *$ & $\mathbf{0 . 1 0}$ & 0.10 & $-1.67 * *$ & 0.09 \\
\hline SFCR 125 & $-0.64 * *$ & 0.32 & 2.97 & $-0.51 * *$ & $-0.51 * *$ & 1.41* & 0.07 \\
\hline \multicolumn{8}{|c|}{ Shoot fly-susceptible restorer lines } \\
\hline ICSV 91011 & $0.16 * *$ & $-23.92 * *$ & $-36.82 * *$ & $0.96 * *$ & $0.74 * *$ & 0.41 & 0.09 \\
\hline CS 3541 & $0.66 * *$ & $-34.96 * *$ & $-\mathbf{5 0 . 1 2}^{* *}$ & 0.38 *** & $0.55 * *$ & $1.17 *$ & 0.09 \\
\hline MR 750 & $0.72 * *$ & $-37.73 * *$ & $-54.93 * *$ & $-0.37 * *$ & 0.05 & 0.67 & 0.07 \\
\hline ICSV 745 & $\mathbf{0 . 6 8} * *$ & $-\mathbf{3 7 . 3 8} * *$ & $-56.08 * *$ & $1.08 * *$ & $1.08 * *$ & $-1.74 * *$ & 0.07 \\
\hline Swarna & $\mathbf{0 . 9 2} * *$ & $-\mathbf{3 3 . 9 2} * *$ & $-46.86^{* *}$ & $-\mathbf{0 . 2 0}$ & 0.21 & $1.59 *$ & 0.12* \\
\hline $\mathbf{S E} \pm(\mathbf{G C A})$ & 0.06 & 3.70 & 3.20 & 0.11 & 0.10 & 0.63 & 0.05 \\
\hline $\mathrm{SE} \pm\left(g_{i}-g_{j}\right)$ & 0.08 & 5.23 & 4.52 & 0.16 & 0.14 & 0.89 & 0.07 \\
\hline
\end{tabular}

* GCA effects significant at $P=0.05$.

** GCA effects significant at $\boldsymbol{P}=\mathbf{0 . 0 1}$.

restoration cytoplasm on resistance-susceptibility to $A$. soccata in sorghum. The equal levels of susceptibility in case of shoot fly-susceptible CMS and shoot fly-resistant or susceptible restorer lines-based hybrids suggested the influence of cytoplasmic factors on expression of shoot fly resistance in sorghum because of interaction of cytoplasmic and nuclear genes. Resistance is required in both male and female parents for obtaining hybrids with resistance to $A$. soccata. Studies on nature of gene action and regression analyses indicated that expression of leaf glossiness, trichomes, plants with eggs, and deadhearts in $\mathrm{F}_{1}$ hybrids was conditioned by additive-type of gene action, and these can be used as morphological markers to select for resistance to sorghum shoot fly.

\section{ACKNOWLEDGMENTS}

We thank Suri Sehgal Foundation for financial support to the senior author and G. Pampapathy, V. Venkateshwara Rao, J. Raja Rao, Madhusudhan Reddy, K. Hareendranath, and S.V.N. Chandra for their help in data collection; and Dr. S. Chandra and Mr. Prasanth for help in statistical analyses.

\section{REFERENCES}

Agrawal, B.L., and C.V. Abraham. 1985. Breeding sorghum for resistance to shoot fly and midge. p. 371-383. In Proc. International Sorghum Entomology Workshop, Texas A\&M University, College Station, Texas, USA.15-21 July 1984. International Crops Research Institute for the Semi-Arid Tropics, Patancheru 502324, Andhra Pradesh, India.
Agrawal, B.L., and L.R. House. 1982. Breeding for pest resistance in sorghum. p. 435-446. In L.R. House et al. (ed.) Sorghum in Eighties, Proc. International Symposium on Sorghum, 2-7 November 1981, International Crops Research Institute for the Semi-Arid Tropics, Patancheru 502324, Andhra Pradesh, India.

Borikar, S.T., and P.R. Chopde. 1982. Genetics of resistance to sorghum shoot fly. Z. Pfl. Zucht. 88:220-224.

Dhillon, M.K. 2004. Effects of cytoplasmic male-sterility on expression of resistance to sorghum shoot fly, Atherigona soccata (Rondani). Ph.D. Thesis, Department of Entomology, Chaudhary Charan Singh Haryana Agricultural University, Hisar, Haryana, India.

Dhillon, M.K., H.C. Sharma, R. Singh, and J.S. Naresh. 2005. Mechanisms of resistance to shoot fly, Atherigona soccata in sorghum. Euphytica 144:301-312.

FAO. 2002. Year Book 56. Food and Agriculture Organization, Rome. Hallali, M.S., B.T.S. Gowda, K.A. Kulkarni, and J.V. Goud. 1982. Inheritance of resistance to shoot fly (Atherigona soccata Rond.) in sorghum (Sorghum bicolor (L.) Moench). SABRAO J. 14:165-170.

Hallali, M.S., B.T.S. Gowda, K.A. Kulkarni, and J.V. Goud. 1983. Evaluation of advanced generation progenies for resistance to shoot fly in sorghum. Indian J. Genet. 43:291-293.

Hallauer, A.R., and J.B. Miranda. 1981. Quantitative genetics in maize breeding. Iowa State Univ. Press, Ames, IA.

House, L.R. 1985. A Guide to Sorghum Breeding. p. 83-84. International Crops Research Institute for the Semi-Arid Tropics, Patancheru 502324, Andhra Pradesh, India.

Jotwani, M.G. 1983. Losses due to shoot fly in high yielding sorghum. p. 213-220. In B.H. Krishnamurthy Rao and K.S.R.K. Murthy (ed.) Crop Losses due to Insect Pests, Special Issue of Indian J. Entomol. Entomological Society of India, Rajendranagar, Hyderabad, Andhra Pradesh, India.

Kempthrone, O. 1957. An Introduction to Genetic Statistics. John Wiley \& Sons, New York, USA.

Maiti, R.K., F.R. Bidinger, K.V. Seshu Reddy, P. Gibson, and J.C. Davies. 1980. Nature and occurrence of trichomes in sorghum lines 
with resistance to sorghum shoot fly. p. 1-33. In Joint Progress Report 3 of Sorghum Physiology and Sorghum Entomology, International Crops Research Institute for the Semi-Arid Tropics, Patancheru 502324, Andhra Pradesh, India.

Maiti, R.K., K.E. Prasada Rao, P.S. Raju, and L.R. House. 1984. The glossy trait in sorghum: Its characteristics and significance in crop improvement. Field Crops Res. 9:279-289.

Mate, S.N., M.R. Manjare, and R.B. Patil. 1996. Correlation studies of shoot fly attack with physiological and chemical factors in Sorghum bicolor (L.) Moench. p. 154. In Proc. 2nd International Crop Science Congress: Crop Productivity and Sustainability-Shaping the Future, 17-24 Nov 1996, Indian Council of Agricultural Research, New Delhi, India.

Rana, B.S., B.U. Singh, and N.G.P. Rao. 1985. Breeding for shoot fly and stem borer resistance in sorghum. p. 347-359. In Proc. International Sorghum Entomology Workshop, 15-21 July 1984, Texas A\&M University, College Station, Texas, USA. International Crops Research Institute for the Semi-Arid Tropics, Patancheru 502324, Andhra Pradesh, India.

Rao, N.G.P., B.S. Rana, K. Balakotiah, and M.F.S. Fayed. 1974. Genetic analysis of some exotic $\times$ Indian crosses in sorghum VIII. $F_{1}$ analysis of ovipositional non-preference underlying resistance to sorghum shoot fly. Indian J. Genet. 34:122-127.

Ravindrababu, Y., and A.R. Pathak. 2000. Combining ability analysis over environments for yield and shoot fly resistance in sorghum. J. Res. Maharashtra Agric. Univ. 25:237-239.

Sharma, G.C., M.G. Jotwani, B.S. Rana, and N.G.P. Rao. 1977. Resistance to the sorghum shoot fly, Atherigona soccata (Rond.) and its genetic analysis. J. Entomol. Res. 1:1-12.

Sharma, H.C. 1993. Host plant resistance to insects in sorghum and its role in integrated pest management. Crop Prot. 12:11-34.

Sharma, H.C., C.V. Abraham, P. Vidyasagar, and J.W. Stenhouse. 1996. Gene action for resistance in sorghum to midge, Contarinia sorghicola. Crop Sci. 36:259-265.

Sharma, H.C., and K.F. Nwanze. 1997. Mechanisms of resistance to insects in sorghum. Information Bulletin No. 45, International Crops Research Institute for the Semi-Arid Tropics, Patancheru 502324, Andhra Pradesh, India.

Sharma, H.C., S.L. Taneja, N. Kameswara Rao, and K.E. Prasada Rao. 2003a. Evaluation of sorghum germplasm for resistance to insect pests. Information Bulletin No. 63, International Crops Research Institute for the Semi-Arid Tropics, Patancheru 502324, Andhra Pradesh, India.

Sharma, H.C., G. Venkateswarulu, and A. Sharma. 2003b. Environmental factors influence the expression of resistance to sorghum midge, Stenodiplosis sorghicola. Euphytica 130:365-375.

Sharma, H.C., P. Vidyasagar, C.V. Abraham, and K.F. Nwanze. 1994 Effect of cytoplasmic male-sterility in sorghum on host plant interaction with sorghum midge, Contarinia sorghicola. Euphytica 74:35-39.

Singh, B.U., B.S. Rana, and N.G.P. Rao. 1981. Host plant resistance to mite (Oligonychus indicus $\mathrm{H}$.) and its relationship with shoot fly (Atherigona soccata Rond.) resistance in sorghum. J. Entomol. Res. 5:25-30.

Soto, P.E. 1974. Ovipositional preference and antibiosis in relation to resistance to sorghum shoot fly. J. Econ. Entomol. 67:265-267.

Starks, K.J., S.A. Eberhart, and H. Doggett. 1970. Recovery from shoot fly attack in a sorghum diallel. Crop Sci. 10:512-519.

Stephens, J.C., and R.F. Holland. 1954. Cytoplasmic male sterility for sorghum seed production. Agron. J. 46:20-23.

Tarumoto, I. 1980. Inheritance of glossiness of leaf blades in sorghum, Sorghum bicolor (L.). Moench. Jpn. J. Breed. 30:237-240.

Xu, Z.G.T., F.M. Kong, X.P. Shen, and M. Cheng. 1998. Forecasting of resistance to bacterial blight in indica hybrid rice and its parents. J. Southwest Agric. Univ. 20:409-413.

Xu, Z.G.T., and H.M. Song. 1997. Resistance to bacterial leaf blight in some CMS lines of rice. Acta Agric. Bor. Sin. 12:46-50.

Yamamoto, A., T. Nakamura, J.J. Adu-Gyamfi, and M. Saigusa. 2002. Relationship between chlorophyll content in leaves of sorghum and pigeonpea determined by extraction method and by chlorophyll meter (SPAD-502). J. Plant. Nutr. 25:2295-2301. 